\title{
Expression of Recombinant Human Follicle-Stimulating Hormone Receptor: Species-Specific Ligand Binding, Signal Transduction, and Identification of Multiple Ovarian Messenger Ribonucleic Acid Transcripts*
}

\author{
JONATHAN L. TILLY ${ }^{\prime}$, TOSHIHIKO AIHARA $\ddagger$ KEIJI NISHIMORI, XIAO-CHI JIA, \\ HAKAN BILLIG, KIM I. KOWALSKI, E. A. PERLAS, AND AARON J. W. HSUEH \\ Division of Reproductive Biology, Department of Gynecology and Obstetrics, Stanford University School of \\ Medicine, Stanford, California 94305-5317
}

\begin{abstract}
The ligand specificity and biochemical properties of the human (h) FSH receptor are poorly characterized due to the low abundance of these receptors and the limited availability of human tissues. Using a fragment of rat FSH receptor cDNA, we screened a human testicular cDNA library and obtained a FSH receptor cDNA covering the entire amino acid-coding region. After transfection of a human fetal kidney cell line (293) with the hFSH receptor cDNA, radioligand receptor analysis revealed the presence of high affinity $\left(\mathrm{K}_{\mathrm{d}}, 1.7 \times 10^{-9} \mathrm{M}\right) \mathrm{FSH}-$ binding sites on the plasma membrane. Both recombinant and wildtype hFSH displaced [ $\left.{ }^{226} \mathrm{I}\right] \mathrm{hFSH}$ binding, with $\mathrm{ED}_{50}$ values of 25 and $70 \mathrm{ng} / \mathrm{ml}$, respectively, whereas hLH, hCG, and hTSH were ineffective. Although human, rat ( $r$ ), and ovine FSH as well as equine CG competed for rat testicular FSH receptor binding, only hFSH and rFSH interacted effectively with the recombinant hFSH receptor, suggesting that species-specific ligand recognition exists between human and rodent receptors. After incubation of transfected cells with hFSH, but not
\end{abstract}

recombinant $\mathrm{hLH}$ or $\mathrm{hCG}$, a dose-dependent increase $\left(\mathrm{ED}_{50}, 10 \mathrm{ng} / \mathrm{ml}\right)$ in extracellular cAMP accumulation was observed, indicating a functional coupling of the expressed human receptor with the endogenous adenyl cyclase. In cells cotransfected with the FSH receptor expression plasmid and a luciferase reporter gene driven by the promoter of a cAMP-responsive gene, treatment with $\mathrm{hFSH}$, but not $\mathrm{hCG}$, resulted in a dose-dependent increase in luciferase activity. Northern blot analysis using a $\mathrm{cRNA}$ probe derived from the human receptor $\mathrm{cDNA}$ indicated the presence of multiple FSH receptor mRNA transcripts (7.0, 4.2, and 2.5 kilobases) in RNA prepared from human follicular phase ovary, but not from human corpus luteum or placenta. Additionally, two FSH-binding sites of 76 and 112 kilodaltons were detected in transfected 293 cells after ligand/receptor cross-linking and sodium dodecyl sulfate-polyacrylamide gel electorphoresis analysis. These results demonstrate the expression of functional $\mathrm{hFSH}$ receptor with unique ligand specificity and provide new data on the biochemical properties of the human receptor at the mRNA and protein levels. (Endocrinology 131: 799-806, 1992)
$\mathrm{F}$ H IS a member of the glycoprotein hormone family that also comprises $\mathrm{LH}, \mathrm{CG}$, and $\operatorname{TSH}(1,2)$. Hormones of this family are dimers consisting of a common $\alpha$-subunit and hormone-specific $\beta$-subunits joined together by noncovalent binding (3). As with the other glycoprotein hormones, FSH binding to target cells increases adenyl cyclase activity through interaction with membrane-associated G-proteins (4), thus classifying the FSH receptor to the G-proteincoupled receptor family (5-7). The hallmark of G-proteincoupled receptors is the presence of seven transmembranespanning segments that possess a homologous cluster of six or seven amino acid residues located on the carboxyl-terminal region of the third cytoplasmic loop. Recent molecular cloning of rat $\mathrm{LH}$ and FSH receptors have indicated that this conserved region, which has been implicated in G-protein coupling of the $\beta$-adrenergic receptor $(8-10)$ and TSH recep-

Received February 7, 1992.

Address all correspondence and requests for reprints to: Dr. Aaron J. W. Hsueh, Division of Reproductive Biology, Department of Obstetrics and Gynecology, Stanford University School of Medicine, 300 Pasteur Drive, Stanford, California 94305-5317.

* This work was supported by NIH Grant HD-23273.

† Postdoctoral fellow supported by the Lalor Foundation.

$\ddagger$ On leave from the Department of Obstetrics and Gynecology, Hokkaido University, Sapporo, Japan tor (11), is also present in the third cytoplasmic loop of gonadotropin receptors $(12,13)$.

Although the importance of FSH in testicular and ovarian development and reproductive function has been unequivocally established (for review, see Refs. 14-16), the limited availability of human gonadal tissues as well as the paucity of gonadal FSH-binding sites have precluded the study of human (h) FSH receptors. Recent studies from our laboratory have indicated that the ligand specificity of human $v s$. rat (r) LH receptors is dramatically different, suggesting that the properties of human gonadotropin receptors may differ from those of experimental animal models (17). To more clearly elucidate the properties of hFSH receptors, we report here the expression of a functional recombinant $\mathrm{hFSH}$ receptor with unique ligand specificity. Furthermore, the distribution of FSH receptor mRNA in human reproductive tissues and the biochemical properties of the expressed receptor are presented.

\section{Materials and Methods}

\section{Reagents and hormones}

Restriction enzymes were obtained from Bethesda Research Laboratories (BRL; Gaithersburg, MD), Boehringer-Mannheim (Indianapolis, IN), and Stratagene (La Jolla, CA). A $\lambda$ gt 11 human testicular cDNA 
library was obtained from Clontech (Palo Alto, CA). The eukaryotic expression vector $\mathrm{pCMX}$ was a gift from Dr. K. Umesono of The Salk Institute (San Diego, CA). The recombinant human gonadotropin preparations were derived from serum-free conditioned medium of Chinese hamster ovary $(\mathrm{CHO})$ cell lines transfected with human gonadotropin genes. The recombinant hLH contains a deletion of seven hydrophobic amino acids at the carboxyl-terminus and a substitution of Trp to Arg at position eight of the $\beta$-subunit for efficient dimerization and secretion from $\mathrm{CHO}$ cells $(18)$. The recombinant hFSH has biological activity and chromatofocusing profiles similar to those of purified pituitary FSH (19). The concentrations of the recombinant gonadotropins were estimated in RIAs using purified pituitary preparations as standards (hLH, hLH I-3, $5,900 \mathrm{IU} / \mathrm{mg}$; hFSH, hFSH I- $3,3,100 \mathrm{IU} / \mathrm{mg}$ by the hCG augmentation assay). hFSH (I-3), hCG (CR-127; 14,900 IU/mg), hLH (B1; 4,015 IU/ $\mathrm{mg}$ ), hTSH (B1; $15 \mathrm{IU} / \mathrm{mg}), \mathrm{rFSH}(\mathrm{I}-7 ; 4,714 \mathrm{IU} / \mathrm{mg})$, and ovine (o) FSH (oFSH-17; $25 \mathrm{IU} / \mathrm{mg}$ ) were obtained from the National Hormone and Pituitary Distribution Program (Bethesda, MD); recombinant hTSH was obtained from Genzyme (Cambridge, MA); equine (e) CG (PMSG; 2,530 $\mathrm{IU} / \mathrm{mg}$ ) was obtained from Calbiochem (La Jolla, CA); and porcine ( $\mathrm{p}$ ) FSH was the gift of Dr. H. Papkoff (University of California-San Francisco). Reagents required for the luciferase assay were purchased from Analytical Luminescence Laboratory (San Diego, CA).

\section{cDNA library screening}

A fragment of rFSH receptor cDNA, corresponding to bases 6211031 of the published sequence (13), was obtained by reverse transcription-polymerase chain reaction of RNA prepared from PMSG-primed rat ovaries (20). This cDNA fragment was radiolabeled by the random priming method (21) and used to screen the human testicular cDNA library (22). Eight positively hybridizing phage clones ranging in size from 1.8-2.2 kilobases $(\mathrm{kb})$ were isolated, subcloned into the pBluescript II SK plasmid (Stratagene), and sequenced using the dideoxy chain termination method (23) with a DNA sequencing kit (U.S. Biochemical Corp., Cleveland, $\mathrm{OH}$ ) and specific primers. Individual fragments obtained from two separate clones (H37 and G3) were prepared by BamHI restriction enzyme digestion and ligated at nucleotide position 686 to yield the final hFSH receptor cDNA construct containing the entire amino acid-coding region. Clone $\mathrm{H} 37$ contains 75-basepairs (bp) of 5'untranslated region plus 1562 bp of open reading frame, but lacks the $3^{\prime}$-end and polyadenylation signal. Clone G3 starts at $168 \mathrm{bp}$ of the open reading frame and covers the entire amino acid-coding region to the termination codon plus 26 bp of the $3^{\prime}$-untranslated region. These clones contain a 1394 -bp overlapping region with identical nucleotide sequence, the identity of which was further confirmed by sequence analysis of the remaining six clones. The DNA sequence of the final clone was determined on both strands and compared to the published sequence of a cloned, but not expressed, human ovarian FSH receptor cDNA (24). Sequence comparison indicated seven individual basepair substitutions between our and the reported clone, resulting in five different amino acids at the following positions: 112 (Thr to Asn), 197 (Ala to Glu), 198 (Val to Leu), 307 (Ala to Thr), and 680 (Ser to Asn).

\section{Expression of full-length cDNA in eukaryotic cells}

An EcoRI linker (Promega, Madison, WI) was inserted into the EcoRV restriction site of the PCMX expression vector (17) to generate a plasmid (designated pCME) containing an EcoRI cloning site. The cDNA construct coding for the entire hFSH receptor $(-75$ to 2085 bp plus 26 bp of the $3^{\prime}$-untranslated region) was then subcloned into the EcoRI site of the pCME vector and partially sequenced to determine the orientation of the cDNA insert. Exponentially growing 293 cells derived from human fetal kidney were transiently transfected in $5 \mathrm{ml}$ Dulbecco's Modified Eagle's Medium (DMEM; supplemented with $5 \%$ fetal calf serum, $2 \mathrm{~mm}$ $\mathrm{L}$-glutamine, $100 \mathrm{U} / \mathrm{ml}$ penicillin, and $100 \mu \mathrm{g} / \mathrm{ml}$ streptomycin sulfate; Gibco, Santa Clara, CA) with the expression plasmid (designated pCMEhFSHK) using the calcium phosphate precipitation method (25) used routinely in our laboratory (17). Twenty-four hours after transfection, FSH receptor binding studies were performed by incubating cells $(2 \times$ $10^{5} / 0.4 \mathrm{ml}$ ) with [ $\left.{ }^{125} \mathrm{I}\right] \mathrm{hFSH}$ at $22 \mathrm{C}$ for $20 \mathrm{~h}$ or as indicated. Iodination of hFSH (I-3) was performed using the lactoperoxidase method (26).
The specific activity and maximal binding of $\left[{ }^{125} \mathrm{I}\right] \mathrm{hFSH}$, as determined by radioligand receptor assay using rat testicular membranes, were $99,000-110,000 \mathrm{cpm} / \mathrm{ng}$ and $7 \%$, respectively. Nonspecific binding was determined by inclusion of a 1,000-fold excess of unlabeled ligand (Pergonal, Serono Laboratories, Randolph, MA). Similar procedures were used to analyze the ligand specificity of FSII-binding siles in testicular homogenates prepared from 15-day-old Sprague-Dawley rats (Johnson Labs, Bridgeview, IL). For cAMP analysis, transfected 293 cells $\left(2 \times 10^{5} /\right.$ culture dish) were treated with various gonadotropins in the presence of $0.25 \mathrm{~mm} 3$-isobutyl-1-methylxanthine (MIX; Sigma Chemical Co., St. Louis, MO) for $2 \mathrm{~h}$ at $37 \mathrm{C}$. After incubation, extracellular cAMP levels were determined by specific RIA, using [ $\left.{ }^{125} \mathrm{I}\right]$ CAMP (ICN, Costa Mesa, CA) as the labeled ligand and a commercially available cAMP antiserum (ICN) (27). The intra- and interassay coefficients of variation were $6 \%$ and $10 \%$, respectively.

\section{Luciferase reporter gene}

A 654-bp fragment of the $5^{\prime}$-flanking sequence of the rat tissue plasminogen activator (tPA) gene ligated to the luciferase gene plasmid p19LUC (28) was used (designated ptPA-LUC) (29). This portion of the tPA promoter region contains a CAMP-responsive element capable of mediating gonadotropin-stimulated tPA gene transcription (29). Exponentially growing 293 cells were transiently transfected in $5 \mathrm{ml}$ DMEM with pCME-hFSHR and ptPA-IUC plasmids (at a ratio of $0.8: 0.2 ; 7.5$ $\mu \mathrm{g}$ total DNA). After transfection, cells were collected, counted, and dispensed into $12 \times 75-\mathrm{mm}$ culture tubes $\left(5 \times 10^{4}\right.$ cells/tube). The total volume was brought to $0.3 \mathrm{ml}$ with DMEM containing $0.25 \mathrm{mM}$ MIX with hFSH or hCG, and cells were incubated for $18 \mathrm{~h}$ at $37 \mathrm{C}$. After incubation, cells were lysed by the addition of $0.3 \mathrm{ml} /$ tube $2 \times$ lysis buffer [ 50 Inм Tris-phosphate (pH 7.8), $4 \mathrm{~mm}$ dithiothrietol, $4 \mathrm{~mm}$ 1,2diaminocyclohexane- $N, N, N^{\prime}, N^{\prime}$-tetraacetic acid, $20 \%$ glycerol, and $2 \%$ Triton $X-100]$ at $22 \mathrm{C}$ for $15 \mathrm{~min}$. For estimation of luciferase activity, $10 \mu \mathrm{l}$ cell lysate mixture were combined with $100 \mu \mathrm{l}$ assay reagent [20 $\mathrm{mM}$ tricine, $1.07 \mathrm{mM}\left(\mathrm{MgCO}_{3}\right)_{4} \mathrm{Mg}(\mathrm{OH})_{2}-5 \mathrm{H}_{2} \mathrm{O}, 2.67 \mathrm{~mm} \mathrm{MgSO}_{4}, 0.1$ mM EDTA, $33.3 \mathrm{~mm}$ dithiothrietol, $270 \mu \mathrm{M}$ coenzyme-A, $470 \mu \mathrm{M}$ luciferin, and $530 \mu \mathrm{M} \mathrm{ATP}$, and light production was immediately measured for $10 \mathrm{sec}$ in a luminometer (Monolight 2010, Analytical Luminescence Laboratory).

\section{Preparation of nucleic acid probe for $h F S H$ receptor $m R N A$}

A fragment of the hFSH receptor CDNA, corresponding to bases $744-$ 1026 , was isolated after digestion of the hFSH receptor CDNA with the Hincll restriction enzyme. This fragment, which possesses less than $50 \%$ nucleotide sequence homology to the hLH receptor cDNA (17), was subcloned into the pGEM $4 z$ vector (Promega). The plasmid clone was linearized with the SalI restriction enzyme and served as a template for the production of a cRNA probe using T7 RNA polymerase (BRL) and $\left[\alpha{ }^{32} \mathrm{P}\right] \mathrm{CTP}(3000 \mathrm{Ci} / \mathrm{mmol}$; Amersham, Arlington Heights, IL), as previously described (30).

\section{Northern blot analysis}

Human ovarian and placental tissues were provided by Dr. T. Tanaka (Hokkaido University, Sapporo, Japan) and Dr. A. Murphy (University of California-San Diego), respectively. Total RNA was extracted from human tissues using the guanidinium thiocyanate-phenol-chloroform extraction procedure (31). Total RNA samples were enriched for poly(A) mRNA by a single round of oligo(dT) column chromatography (Pharmacia LKB Biotechnology, Piscataway, NJ) and electrophoresed through $1 \%$ agarose- $2.2 \mathrm{M}$ formaldehyde gels. Samples were blotted onto nitrocellulose membranes (Schleicher and Schuell, Keene, $\mathrm{NH}$ ) by overnight capillary electrophoresis and covalently cross-linked using a UV crosslinker (Stratagene). Membranes were then prehybridized for $2-4 \mathrm{~h}$ at 65 $\mathrm{C}$ in the presence of $50 \%$ formamide under standard conditions, followed by hybridization with the radiolabeled hFSH receptor cRNA probe at the same temperature for $18-20 \mathrm{~h}(20,32,33)$. Membranes were washed in $2 \times$ sodium chloride-sodium citrate (SSC) $-0.1 \%$ sodium dodecyl sulfate (SDS) for $10 \mathrm{~min}$ at room temperature, followed by two or three consecutive 15 - to 20 -min washes in $0.1 \times$ SSC $-0.1 \%$ SDS at 
$65 \mathrm{C}$, and exposed to Kodak X-Omat film (Eastman Kodak, Rochester, NY) for $1-5$ days at $-70 \mathrm{C}$.

\section{Ligand receptor cross-linking}

Cross-linking of $\left[{ }^{125} \mathrm{I}\right] \mathrm{hFSH}$ to binding sites in transfected 293 cells and rat testicular homogenates was performed using disuccinimidyl suberate (Pierce, Rockford, IL), as previously described (34). Briefly, $6 \times$ $10^{6}$ transfected 293 cells or homogenate from 10 immature rat testes were incubated with $8 \times 10^{5} \mathrm{cpm}\left[{ }^{125} \mathrm{I}\right] \mathrm{hFSH}$ in the absence or presence of a 1000 -fold excess of unlabeled hormone at $22 \mathrm{C}$ for $20 \mathrm{~h}$ in a total volume of $0.4 \mathrm{ml}$. After incubation, cells or homogenates were diluted with $1 \mathrm{ml}$ wash solution (Dulbecco's PBS containing $0.1 \%$ BSA, $5 \mathrm{~mm}$ EDTA, and $5 \mathrm{~mm} N$-ethylmaleimide), pelleted by centrifugation, washed, and recentrifuged. Pellets were then resuspended in $0.5 \mathrm{ml}$ incubation buffer (D-PBS containing 10\% dimethylsulfoxide), and disuccinimidyl suberate (freshly prepared in dimethylsulfoxide) was added to a final concentration of $1.5 \mathrm{~mm}$. Cross-linking was carried out at $0 \mathrm{C}$ for 30 min, and the reaction was stopped by the addition of $1 \mathrm{ml}$ termination buffer [ $50 \mathrm{~mm}$ Tris- $\mathrm{HCl}(\mathrm{pH} 7.5)$ and $100 \mathrm{~mm} \mathrm{NaCl}]$. The reaction tubes were centrifuged, and pellets were resuspended in $0.1 \mathrm{ml}$ solubilization buffer [ $50 \mathrm{~mm}$ Tris- $\mathrm{HCl}(\mathrm{pH} 7.5)$ and $1 \%$ Triton $\mathrm{X}-100]$. Solubilization was performed by incubation at $0 \mathrm{C}$ for $60 \mathrm{~min}$, with mixing of samples every $15 \mathrm{~min}$. The samples were centrifuged for $5 \mathrm{~min}$ at $13,000 \times g$, and the resultant supernatants were resolved by SDS-polyacrylamide gel electrophoresis (SDS-PAGE), using $8.5 \%$ polyacrylamide gels. The gels were then subjected to autoradiography at $-70 C$ for $2-14$ days.

\section{Results}

\section{Expression and binding kinetics of hFSH receptors in} eukaryotic cells

Cells derived from a human fetal kidney cell line (293) were transfected with the plasmid pCME-hFSHR. After a 24- $\mathrm{h}$ incubation, cells were analyzed by radioligand receptor binding (Fig. 1). A dose-dependent increase in specifically bound $\left[{ }^{125} \mathrm{I}\right] \mathrm{hFSH}$ was detected in transfected cells incubated with increasing concentrations of labeled FSH, whereas no

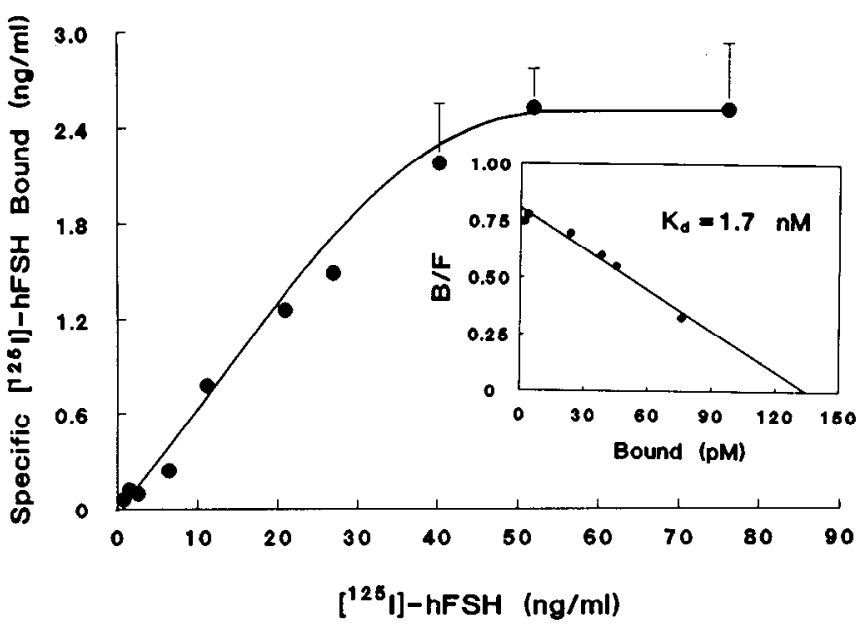

FIG. 1. Binding of $\left[{ }^{125} \mathrm{I}\right] \mathrm{hFSH}$ to hFSH receptors expressed in eukaryotic cells. 293 cells were transfected with the hFSH receptor plasmid pCME-hFSHR, and binding of radiolabeled hFSH was determined 24 $\mathrm{h}$ later. Cells $\left(2 \times 10^{5} /\right.$ tube $\left.\times 0.4 \mathrm{ml}\right)$ were incubated with increasing concentrations of $\left.{ }^{125} \mathrm{I}\right] \mathrm{hFSH}$ in the absence or presence of a 1000 -fold excess of unlabeled ligand. Levels of specifically bound $\left[{ }^{125} \mathrm{I}\right] \mathrm{hFSH}$ are shown together with the derived Scatchard plot (inset; B/F, bound to free ratio). Data are the mean \pm SEM of triplicate determinations from a representative experiment. specific binding was observed in nontransfected cells (data not shown). Analysis of receptor binding indicated a $K_{d}$ value of $1.7 \times 10^{-9} \mathrm{M}$.

To study the effects of incubation time and temperature on the kinetics of FSH receptor binding, transfected 293 cells were incubated with $\left[{ }^{125} \mathrm{I}\right] \mathrm{hFSH}$ at 4,22 , or $37 \mathrm{C}$ for increasing lengths of time, after which specific binding was determined (Fig. 2). A time-dependent increase in the levels of specific FSH binding was observed in cells incubated at 22 and 37 $\mathrm{C}$, whereas low levels of $\left[{ }^{125} \mathrm{I}\right] \mathrm{hFSH}$ binding were detected at $4 \mathrm{C}$. Maximal FSH binding was highest in cells incubated at $22 \mathrm{C}$, although the time required to reach maximal ligand binding was considerably longer in incubations conducted at 22 vs. $37 \mathrm{C}$ (Fig. 2).

\section{Interaction of hFSH receptor with recombinant and pituitary/ urinary-derived human gonadotropins and TSH}

To test the binding specificity of the expressed hFSH receptor for human gonadotropins, transfected 293 cells were incubated with $\left[{ }^{125} \mathrm{I}\right] \mathrm{hFSH}$ in the absence or presence of increasing doses of unlabeled urinary-derived hCG, or hFSH, $\mathrm{hLH}$, or hTSH of both pituitary and recombinant origin. Displacement of labeled FSH from its binding sites was expressed relative to the total amount of specifically bound $\left[{ }^{125} \mathrm{I}\right]$ hFSH (Fig. 3). Both recombinant and pituitary FSH preparations competed with $\left[{ }^{125} \mathrm{I}\right] \mathrm{hFSH}$ for $\mathrm{FSH}$ receptors expressed in 293 cells (ED ${ }_{50}$ : recombinant, $25 \mathrm{ng} / \mathrm{ml}$; pituitary-derived, $70 \mathrm{ng} / \mathrm{ml}$ ), whereas human pituitary LH and

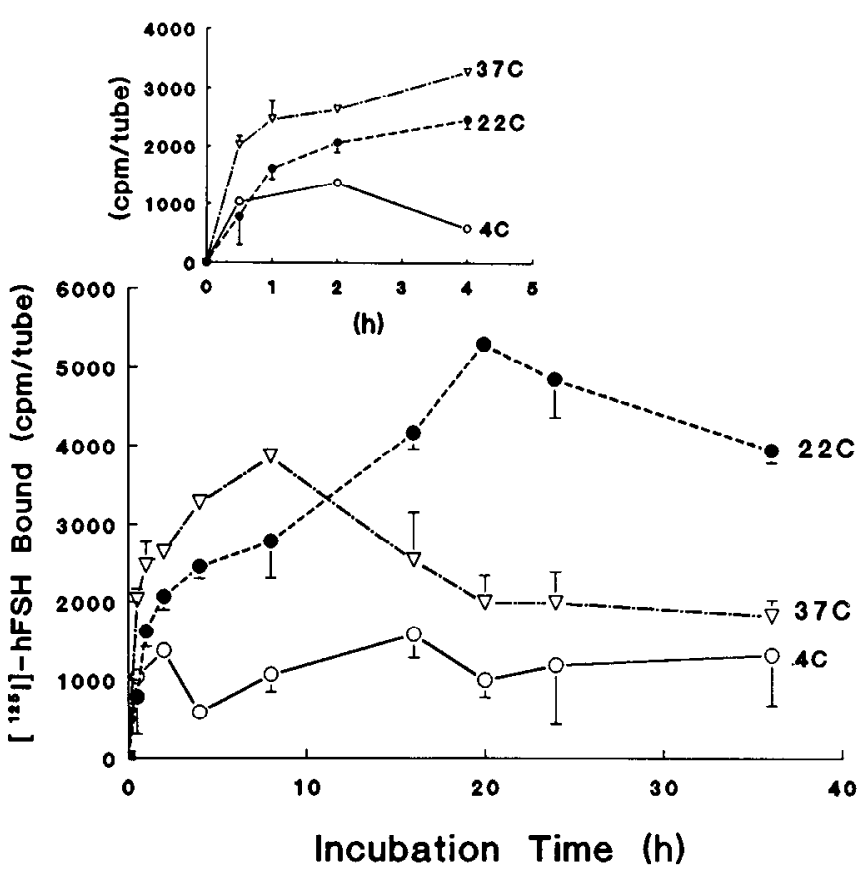

FIG. 2. Effects of incubation time and temperature on rate and extent of $\left[{ }^{125} \mathrm{I}\right]$ hFSH binding to 293 cells. Transfected 293 cells $\left(2 \times 10^{5} /\right.$ tube $)$ expressing hFSH receptors were incubated with radiolabeled hFSH in the absence or presence of a 1000 -fold excess of ligand at 4,22 , or 37 $\mathrm{C}$ for increasing lengths of time, after which levels of specifically bound $\left[{ }^{125} \mathrm{I}\right] \mathrm{hFSH}$ were calculated (mean \pm SEM of triplicate determinations from a representative experiment). An enlarged figure for the first $4 \mathrm{~h}$ of incubation is presented in the inset. 


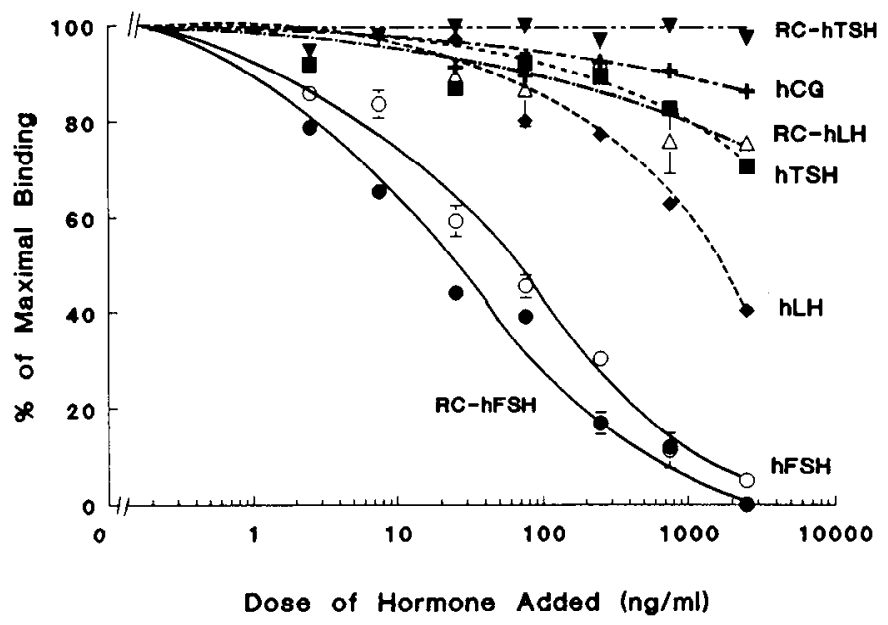

FIG. 3. Interaction of recombinant (RC) and pituitary/urinary-derived human gonadotropins and TSH with hFSH receptors expressed in transfected 293 cells. Displacement of $\left[{ }^{125} \mathrm{I}\right] \mathrm{hFSH}$ binding to hFSH receptors by $\mathrm{hFSH}, \mathrm{hLH}, \mathrm{hCG}$, or hTSH was determined in radioligand receptor assays (mean $\pm S E M$ of three replicate experiments).

TSH were effective only at high doses. In contrast, negligible interaction of hCG or recombinant hLH or hTSH with the expressed FSH receptors was observed (Fig. 3).

\section{Ligand specificity of human vs. rat FSH receptors}

To assess the ligand specificity of the hFSH receptor, 293 cells expressing human receptors were incubated with $\left[{ }^{125} \mathrm{I}\right]$ $\mathrm{hFSH}$ in the absence or presence of increasing doses of eCG (PMSG) or FSH from human, rat, ovine, and porcine origin. Displacement of $\left.{ }^{125} \mathrm{I}\right] \mathrm{hFSH}$ by unlabeled hormone in the human receptor was compared to that of testicular homogenates from 15-day-old rats (Fig. 4). hFSH and rFSH preparations were effective in binding to the recombinant $\mathrm{hFSH}$ receptor $\left(\mathrm{ED}_{50}: \mathrm{hFSH}, 70 \mathrm{ng} / \mathrm{ml} ; \mathrm{rFSH}, 125 \mathrm{ng} / \mathrm{ml}\right)$, whereas only minimal interaction of oFSH, pFSH, or eCG with hFSH receptors was observed (Fig. 4A). In contrast, FSH from rat, human, and ovine origin as well as eCG effectively competed with radiolabeled FSH for binding sites in rat testicular homogenates (hFSH $=\mathrm{rFSH}>\mathrm{oFSH}>\mathrm{eCG}$ ); however, pFSH was effective only at high doses (Fig. 4B).

Gonadotropin stimulation of cAMP production and $t P A$ promoter-luciferase reporter gene by transfected 293 cells expressing $h F S H$ receptors

The functional capacity of the recombinant hFSH receptor was tested based on gonadotropin stimulation of cAMP production by transfected 293 cells. Treatment of cells with human pituitary FSH caused a dose-dependent increase in cAMP formation $\left(E D_{50}, 10 \mathrm{ng} / \mathrm{ml}\right)$, with a maximal 13 -fold increase observed in response to $100 \mathrm{ng} / \mathrm{ml} \mathrm{FSH} \mathrm{(Fig.} \mathrm{5A).}$ Human pituitary LH also increased cAMP production at doses of 100 (4-fold) and 1000 (6.6-fold) $\mathrm{ng} / \mathrm{ml}$, whereas neither hCG nor recombinant hLH altered cAMP levels compared to control values (Fig. 5A).

Our earlier data demonstrated the stimulation of rat tPA
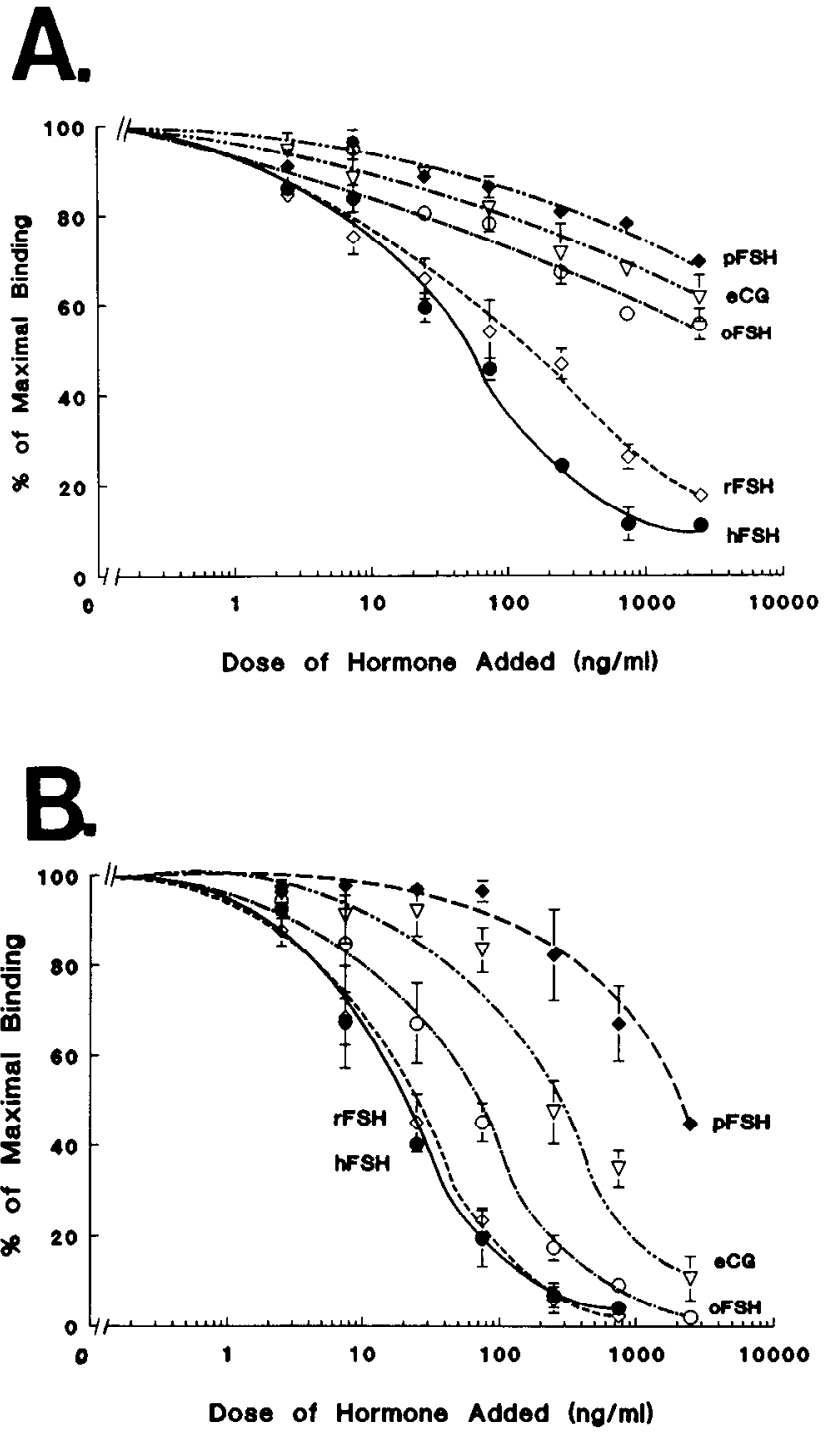

Fic. 4. Displacement of $\left.{ }^{125} \mathrm{I}\right] \mathrm{hFSH}$ binding to human and rat FSH receptors by human, rat, ovine, equine, and porcine gonadotropins. Transfected 293 cells expressing hFSH receptors (A) or rat testicular homogenates (B) were incubated with $\left[{ }^{125} \mathrm{I}\right] \mathrm{hFSH}$ in the absence or presence of $\mathrm{hFSH}, \mathrm{rFSH}$, oFSH, or pFSH as well as eCG. Displacement curves are presented as a percentage of maximal binding at each dose of unlabeled hormone (mean \pm SEM of three replicate experiments).

gene expression in ovarian granulosa cells (32). In granulosa cells transfected with a luciferase reporter gene driven by a cAMP-responsive region of the rat $\mathrm{PAA}$ gene promoter, treatment with FSH increases luciferase expression (29). Using this tPA-luciferase reporter plasmid, we evaluated the ability of human gonadotropins to induce luciferase activity in 293 cells transfected with plasmids for both hFSH receptor and the reporter constructs. Treatment of cells with increasing doses of FSH, but not hCG, caused a dose-dependent increase in luciferase activity, with an estimated $\mathrm{ED}_{50}$ of $8 \mathrm{ng} /$ $\mathrm{ml}$ and a maximal 2 -fold increase at $100 \mathrm{ng} / \mathrm{ml}$ (Fig. 5B). These findings demonstrate a functional linkage of recombinant $h F S H$ receptors to the $\mathrm{tPA}$ gene. 

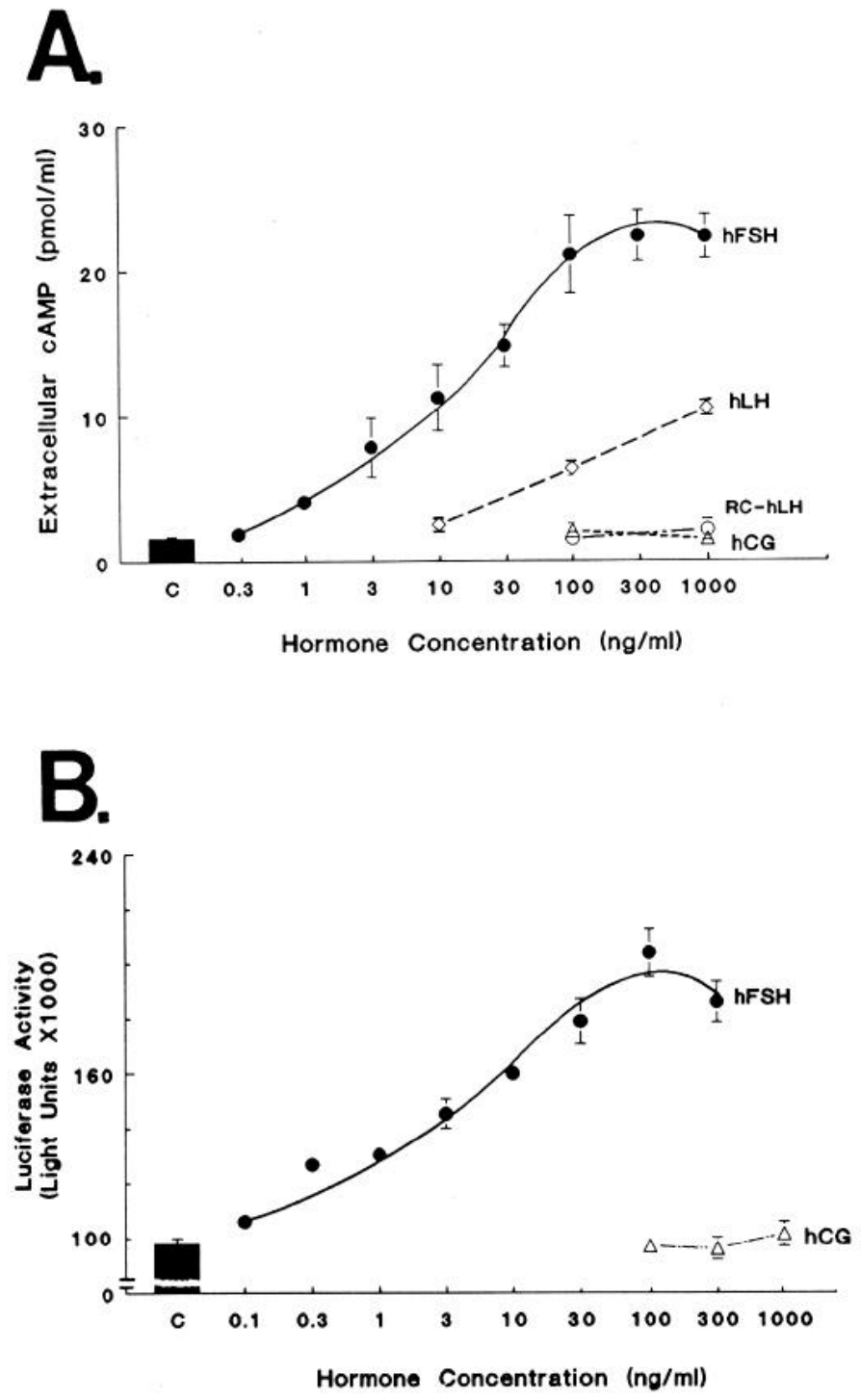

FIG. 5. Gonadotropin stimulation of cAMP production (A) and luciferase activity (B) by 293 cells expressing hFSH receptors. A, Extracellular cAMP accumulation was measured after incubation of transfected 293 cells $\left(2 \times 10^{5} /\right.$ culture dish) for $2 \mathrm{~h}$ at $37 \mathrm{C}$ with $0.25 \mathrm{~mm}$ MIX in the absence or presence of hFSH, hLH, or hCG. Data are the mean \pm SEM of six cultures from three replicate experiments (RC, recombinant). B, Dose-dependent stimulation of luciferase activity by hFSH, but not hCG, in 293 cells cotransfected with the hFSH receptor plasmid and a tPA promoter-luciferase reporter gene construct (note the break in the y-axis). Data are the mean \pm SEM of triplicate determinations from a representative experiment.

\section{Northern blot analysis of FSH receptor mRNAs in human reproductive tissues}

To study the expression of hFSH receptor mRNA, RNA was extracted from human reproductive tissues and analyzed by Northern blot, using a radiolabeled cRNA probe corresponding to the extracellular region of cDNA from our cloned hFSH receptor (Fig. 6). Analysis of poly(A)-enriched mRNA prepared from human follicular phase ovary indicated the

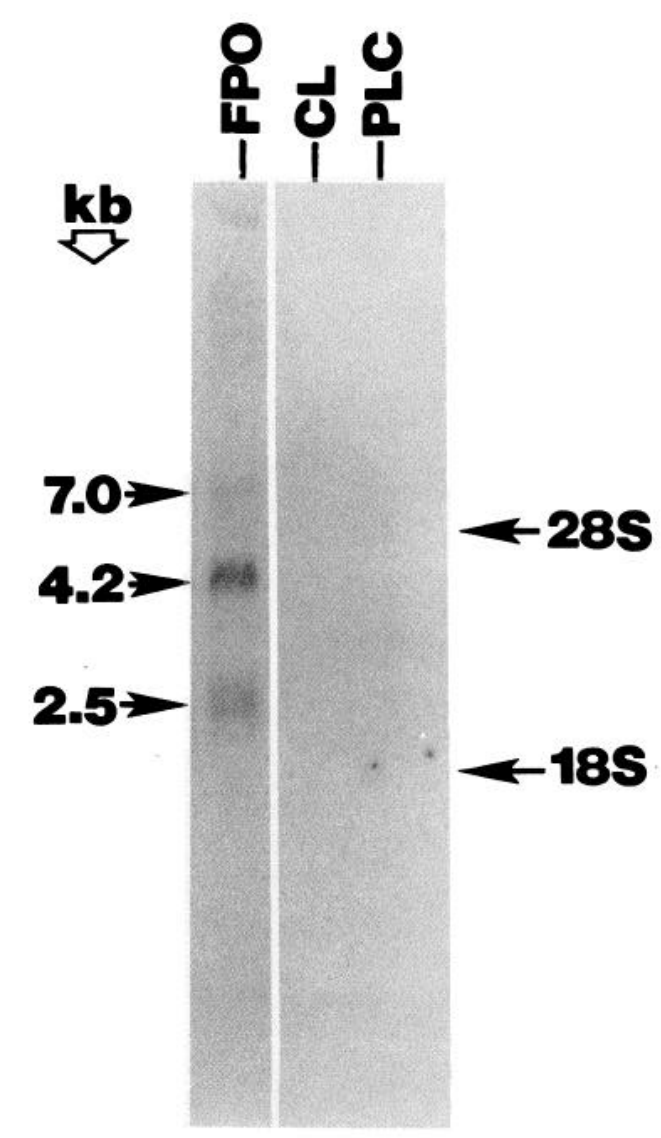

FIG. 6. Northern blot analysis of hFSH receptor mRNAs in human reproductive tissues. Poly(A)-enriched RNA samples prepared from human follicular phase ovary (FPO), 21-day-old corpora lutea (CL), or 19-week-old placenta (PLC) ( $2 \mu \mathrm{g} /$ lane) were resolved through denaturing agarose gels, transferred to nitrocellulose filters, and hybridized to a ${ }^{32} \mathrm{P}$-labeled hFSH receptor $\mathrm{cRNA}$ probe. Filters were washed and exposed to photographic films for 5 days at $-70 \mathrm{C}$. Migration distances of the $28 \mathrm{~S}$ and $18 \mathrm{~S}$ ribosomal RNAs of a parallel total RNA sample from human ovary are indicated.

existence of three mRNA transcripts $(7.0,4.2$, and $2.5 \mathrm{~kb})$ that were not detected in an equivalent amount of mRNA prepared from corpus luteum (day 21 of the menstrual cycle) or placenta (week 19 of pregnancy; Fig. 6).

\section{Cross-linking of $\left[{ }^{125} I\right]$ hFSH to FSH-binding sites in transfected cells and immature rat testes}

To estimate the molecular size of the recombinant hFSH receptor, $\left[{ }^{125} \mathrm{I}\right] \mathrm{hFSH}$ was cross-linked to FSH-binding sites in transfected 293 cells using disuccinimidyl suberate, followed by SDS-PAGE analysis (Fig. 7). A predominant autoradiographic band of protein, with an estimated molecular mass of 109 kilodaltons $(\mathrm{kDa} ; 76 \mathrm{kDa}$ for the binding protein after correction for mass attributed to the ligand) was detected in transfected cells expressing hFSH receptors, whereas a 1000fold excess of ligand completely blocked $\left[{ }^{125} \mathrm{I}\right] \mathrm{hFSH}$ binding (Fig. 7). A less abundant protein band of approximately 145 $\mathrm{kDa}(112 \mathrm{kDa}$ for the binding protein) was also present. These findings were comparable to those observed for FSH 


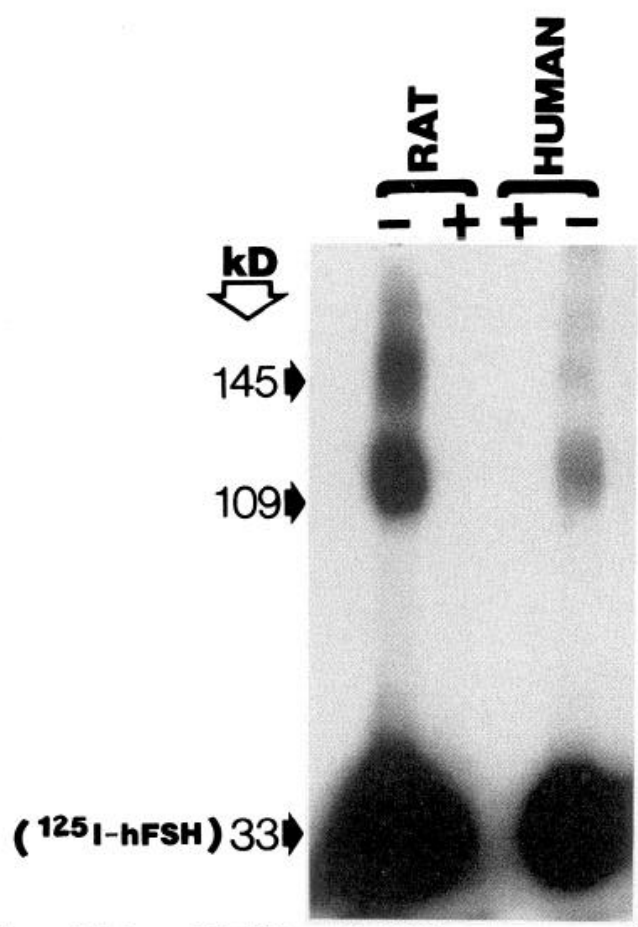

Fig. 7. Cross-linking of hFSH- and rFSH-receptors to [ $\left.{ }^{125} \mathrm{I}\right] \mathrm{hFSH}$. Radiolabeled hFSH was cross-linked to $\mathrm{FSH}$ receptors in transfected 293 cells expressing hFSH receptors (HUMAN) or rat testicular homogenates (RAT) using disuccinimidyl suberate. Proteins were separated through $8.5 \%$ polyacrylamide gels and analyzed by autoradiography ( 14 days at $-70 \mathrm{C}$ ). The sizes of the proteins were estimated by comparison to migration distances of known protein mol wt standards. Symbols indicate the absence $(-)$ or presence $(+)$ of a 1000 -fold excess of ligand (Pergonal) during the binding incubation period before the cross-linking reaction.

receptors found in testicular homogenates of immature rats under the same experimental conditions (Fig. 7).

\section{Discussion}

We report here the ligand specificity and biochemical properties of the recombinant $h F S H$ receptor. Our data indicate that $\mathrm{hFSH}$, but not $\mathrm{LH}$ or CG, competes with $\left[{ }^{125} \mathrm{I}\right]$ $\mathrm{hFSH}$ for binding to the recombinant $\mathrm{FSH}$ receptor. In addition, hFSH stimulates cAMP production in 293 cells expressing the human receptor, whereas recombinant $\mathrm{hLH}$ and hCG are without effect. As a result of stimulation of endogenous cAMP levels by FSH, a tPA promoter-driven luciferase reporter gene was also activated. Similar to the speciesspecific ligand binding recently reported for the $\mathrm{hLH}$ receptor (17), the recombinant $\mathrm{hFSH}$ receptor interacts with $\mathrm{hFSH}$ and $\mathrm{rFSH}$, but only minimally with eCG or FSH of ovine and porcine origins. We also report here the first identification of FSH receptor mRNA in human ovaries as well as the determination of the molecular size of the recombinant hFSH receptor through ligand cross-linking analysis.

Comparison of the present human testicular FSH receptor cDNA with an ovarian cDNA clone recently reported (24) indicated seven individual basepair substitutions throughout the receptor sequence, resulting in five amino acid changes.
Although we are uncertain of the basis for the observed disparity between our and the reported clone, our FSH receptor cDNA could be expressed, whereas no expression data were reported for the ovarian clone. Additionally, four of the five variant amino acids are identical between our $\mathrm{hFSH}$ and the reported $\mathrm{rFSH}$ receptor sequence (13). The ability of 293 cells transfected with our cDNA to express high affinity FSH receptors coupled to the endogenous adenyl cyclase and a luciferase reporter gene indicates that our clone encodes for a functional protein.

The availability of a cell line that expresses recombinant $\mathrm{hFSH}$ receptors has provided an unlimited source of the human receptor and enabled us to perform analysis of the ligand specificity of the human receptor. Radioligand receptor assays demonstrated that the hFSH receptor does not interact with hCG or recombinant hLH or hTSH at physiological or supraphysiological concentrations. However, highly purified human pituitary LH and TSH did cross-react with recombinant FSH receptors, suggesting that the pituitary hormone preparations contain minor FSH contamination. Furthermore, unlike the ability of rat testicular FSH receptors to recognize gonadotropin preparations from diverse species (Ref. 35 and the present study), the human receptor interacted preferentially with human and rat FSH. These findings coupled with a similar species-specific ligand binding of hLH receptors (17) indicate significant evolutionary changes in both human gonadotropin receptors. Alternatively, we cannot rule out subtle differences in posttranslational processing of the receptor in 293 cells vs. gonadal cells that may influence its binding characteristics. However, the ligand specificity of hLH-binding sites expressed in 293 cells (17) is identical to that of native LH receptors present in human corpus luteum (36), suggesting that the properties of these recombinant proteins are similar to those of endogenous gonadal receptors.

Saturation binding and Scatchard analysis demonstrated that the recombinant FSH-binding site has an estimated $\mathrm{K}_{\mathrm{d}}$ of $1.7 \mathrm{nM}$, comparable to that reported for FSH receptors in human testes (37). In addition, the effects of incubation time and temperature on the rate and extent of $\left[{ }^{125} \mathrm{I}\right] \mathrm{hFSH}$ binding by recombinant $\mathrm{hFSH}$ receptors were similar to those reported for rat testicular FSH (35) and LH (38) receptors. Recombinant $\mathrm{hFSH}$ receptors occupied by gonadotropin are also capable of interacting with the endogenous G-proteins of the 293 cells to increase cAMP formation, thus providing a useful model to study FSH-activated signal transduction. Additionally, the use of a luciferase reporter gene driven by the cAMP-responsive promoter of the rat tPA gene (29) has indicated that transfected cells expressing hFSH receptors respond to FSH with increased luciferase activity. These findings provide evidence that FSH-induced signal transduction in cells expressing recombinant $\mathrm{hFSH}$ receptors is coupled to the activation of genes that are regulated by gonadotropins under physiological conditions within gonadal cells (32). However, the relatively small magnitude of the FSH response using the luciferase system (compared to cAMP) suggests a potential limitation of this assay in its present form. The reasons for this observation are unclear, but may 
be related to the lack of gonadal cell-specific transcription factors in 293 cells that limit the activation of the luciferase reporter gene construct. Nonetheless, future modifications of the present cell model and the cAMP-driven luciferase gene reporter system should provide a useful and sensitive bioassay for hFSH.

The availability of hFSH receptor cDNA enabled us to study FSH receptor mRNA transcripts within human reproductive tissues. Northern blot analysis revealed the existence of several FSH receptor mRNAs within human follicular phase ovary, consistent with those reported for multiple FSH receptor mRNA transcripts in rat gonadal tissues $(20,39,40)$. However, RNA prepared from human corpora lutea did not contain detectable levels of this message, suggesting that ovarian FSH receptor mRNA levels undergo up- and downregulation during the human menstrual cycle in a manner similar to that reported for experimental animal models (20, 41).

Based on the deduced amino acid sequence of the hFSH receptor $\mathrm{CDNA}$, the calculated molecular mass of the mature protein is approximately $75.6 \mathrm{kDa}$, consistent with the size estimation of recombinant FSH receptor based on ligand cross-linking and SDS-PAGE and comparable to that observed for FSH receptors in immature rat testes. Of interest was the finding of a less abundant 112-kDa FSH-binding site in both transfected 293 cells and rat testes, presumably resulting from posttranslational glycosylations of the protein. Alternatively, the smaller FSH-binding site may arise from proteolytic cleavage of the larger $112-\mathrm{kDa}$ protein, as has been suggested by previous studies on hCG-binding sites in rat gonadal tissues (42).

Previous studies using nonreducing PAGE followed by ligand blotting have estimated the size of the FSH receptor in bovine and rat testicular membranes to be approximately $240 \mathrm{kDa}(43,44)$, possibly resulting from receptor aggregation and dimer formation. Moreover, photoaffinity labeling of the pFSH receptor revealed the presence of a major crosslinked complex of $104 \mathrm{kDa}$, which could be reduced with dithiothrietol into two smaller complexes of 75 and $61 \mathrm{kDa}$ (45). Although the reasons for the discrepancy between our and earlier findings are unclear, they may result from varying methodologies (e.g. ligand-receptor cross-linking vs. ligand blotting) or species differences. Our data, however, suggest that binding of FSH does not require prior dimerization of its receptor on the plasma membrane, although it is possible that receptor aggregation may be important for receptor stability and/or signal transduction (46).

Expression of the $\mathrm{hFSH}$ receptor provides unlimited material for future studies of clinical interest. Additionally, the ability to measure cAMP production and luciferase reporter gene activity in a cell line expressing hFSH receptors should allow the establishment of a sensitive bioassay for human gonadotropins and for screening new FSH agonists and antagonists. Because earlier reports have suggested the presence of circulating antibodies against FSH receptor in patients with premature ovarian failure (47-49), the etiology of pathophysiological conditions associated with gonadotropin receptor dysfunction may also be more clearly elucidated.

\section{Note Added in Proof}

Amplification of human ovarian and testicular mRNA by reverse transcription polymerase chain reaction with oligonucleotide primers specific for human FSH receptor cDNA sequences, followed by direct sequencing of resultant PCR products after T7 gene 6 exonuclease treatment $(50)$, indicated $100 \%$ sequence identity of this human FSH receptor $\mathrm{CDNA}$ with our clone obtained by cDNA library screening. Furthermore, independent cluning of human FSH receplor CDNA by $R$. Dijkema and R. de Leeuw (Organon, Oss, the Netherlands) also indicated $100 \%$ sequence identity with our cDNA clone (personal communication). Accession no. M95489.

\section{Acknowledgments}

The authors thank Dr. T. Ny (University of Umea, Umea, Sweden) for the rat IPA promoter-luciferase reporter gene; Drs. M. Oikawa and P.S. LaPolt for polymerase chain reaction analysis of the $\mathrm{TFSH}$ receptor cDNA; Dr. I. Boime (Washington University, St. Louis, MO) for provision of $\mathrm{CHO}$ cells secreting human LH and FSH; Dr. K. Umesono (The Salk Institute, San Diego, CA) for the pCMX expression vector and 293 cell line; Dr. T. Tanaka (Hokkaido University, Sapporo, Japan) for human ovarian tissues; Dr. A. Murphy (University of California-San Diego) for human placental tissue; Dr. H. Papkoff (University of California-San Francisco) for the gift of pFSH; and the National Hormone and Pituitary Distribution Program (Bethesda, MD) for hFSH, hLH, hCG, hTSH, rFSH, and oFSH.

\section{References}

1. Pierce JG, Parsons TF 1981 Glycoprotein hormones: structure and function. Annu Rev Biochem 50:465-495

2. Ryan RJ, Charlesworth MC, McCormick DJ, Milius RP, Keutmann HT 1988 The glycoprotein hormones: recent studies of structure-function relationships. FASEB J 2:2661-2669

3. Kourides IA, Gurr JA, Wolf O 1984 The regulation and organization of thyroid stimulating hormone genes. Recent Prog Horm Res 40:79-120

4. Reichert Jr LE, Dattatreyamurty B 1989 The follicle-stimulating hormone (FSH) receptor in testis: interaction with FSH, mechanism of signal transduction, and properties of the purified receptor. Biol Reprod 40:13-26

5. Keinanen KP, Rajaniemi HJ 1986 Rat ovarian lutropin receptor is a transmembrane protein. Biochem J 239:83-87

6. Lefkowitz RJ, Caron MG 1988 Adrenergic receptors. Models for the study of receptors coupled to guanine nucleotide regulatory proteins. J Biol Chem 263:4993-4996

7. Birnbaumer L, Abramowitz J, Brown AM 1990 Receptor-effector coupling by G proteins. Biochim Biophys Acta 1031:163-224

8. Kobilka B 1992 Adrenergic receptors as models for G proteincoupled receptors. Annu Rev Neurosci 15:87-114

9. Strader CD, Dixon RAF, Cheung AH, Candelore MR, Blake AD, Sigal IS 1977 Mutations that uncouple the $\beta$-adrenergic receptor from Gs and increase agonist efficiency. J Biol Chem 262:1643916443

10. Kobilka BK, Kobilka TS, Daniel K, Regan JW, Caron MC, Lefkowitz RJ 1988 Chimeric $\alpha 2$ and $\beta 2$-adrenergic receptors: delineation of domains involved in effector coupling and ligand binding specificity. Science 240:1310-1316

11. Chazenbalk GD, Nagayama $Y$, Russo D, Wadsworth HL, Rapoport B 1990 Functional analysis of the cytoplasmic domains of the human thyrotropin receptor by site-directed mutagenesis. J Biol Chem 265:20970-20975

12. McFarland KC, Sprengel R, Phillips HS, Kohler M, Rosemblit N, Nikolics K, Segaloff DL, Seeburg PH 1989 Lutropin-chorionogonadotropin receptor: an unusual member of the $G$ protein-coupled receptor family. Science 245:494-499

13. Sprengel R, Braun T, Nikolics K, Segaloff DL, Seeburg PH 1990 The testicular receptor for follicle-stimulating hormone: structure and functional expression of cloned cDNA. Mol Endocrinol 4:525- 
530

14. Means AR, Fakunding JL, Huckins C, Tindall DJ, Vitale R 1976 Follicle-stimulating hormone, the Sertoli cell, and spermatogenesis. Recent Prog Horm Res 32:477-527

15. Richards JS 1980 Maturation of ovarian follicles: actions and interactions of pituitary and ovarian hormones on follicular cell development. Physiol Rev 60:51-89

16. Hsueh AJW, Bicsak TA, Jia X-C, Dahl KD, Fauser BCJM, Galway AB, Czekala N, Pavlou SN, Papkoff H, Keene J, Boime I 1989 Granulosa cells as hormone targets: the role of biologically active follicle-stimulating hormone in reproduction. Recent Prog Horm Res 45:209-277

17. Jia X-C, Oikawa M, Bo M, Tanaka T, Ny T, Boime I, Hsueh AJW 1991 Expression of human luteinizing hormone (LH) receptor: interaction with $\mathrm{LH}$ and chorionic gonadotropin from human but not equine, rat, and ovine species. Mol Endocrinol 5:759-768

18. Matzuk MM, Spangler MM, Camel M, Suganuma N, Boime I 1989 Mutagenesis and chimeric genes define determinants in the $\beta$ subunits of human chorionic gonadotropin and lutropin for secretion and assembly. J Cell Biol 109:1429-1438

19. Keene JL, Matzuk MM, Otani T, Fauser BCJM, Galway AB, Hsueh AJW, Boime I 1989 Expression of biologically active human follitropin in Chinese hamster ovary cells. J Biol Chem 264:47694775

20. LaPolt PS, Tilly JL, Aihara T, Nishimori K, Hsueh AJW 1992 Gonadotropin-induced up- and down-regulation of ovarian FSH receptor gene expression: effects of PMSG, hCG and recombinant FSH. Endocrinology 130:1289-1295

21. Feinberg AP, Vogelstein B $1983 \Lambda$ technique for radiolabeling DNA restriction endonuclease fragments to high specific activity. Anal Biochem 132:6-13

22. Maniatis T, Fritsch EF, Sambrook J 1982 Molecular Cloning-A Laboratory Manual. Cold Spring Harbor Laboratory, Cold Spring Harbor

23. Hattori M, Sakai Y 1986 Dideoxy sequencing method using denatured plasmid templates. Anal Biochem 15:232-238

24. Minegish T, Nakamura K, Takakura Y, Ibuki Y, Igarashi M 1991 Cloning and sequencing of human FSH receptor cDNA. Biochem Biophys Res Commun 175:1125-1130

25. Chen C, Okayama $\mathbf{H} 1987$ High efficiency transformation of mammalian cells by plasmid DNA. Mol Cell Biol 7:2745-2752

26. Miyachi Y, Vaitukaitis JL, Nieschlag E, Lipsett MB 1972 Enzymatic radioiodination of gonadotropins. J Clin Endocrinol Metab $34: 23-28$

27. Davoren JB, Hsueh AJW 1985 Vasoactive intestinal peptide: a novel stimulator of steroidogenesis by cultured rat granulosa cells. Biol Reprod 33:37-52

28. De Wet JR, Wood KV, DeLuca M, Helinski DR, Subramani S 1987 Firefly luciferase gene: structure and expression in mammalian cells. Mol Cell Biol 7:725-737

29. Feng P, Ohlsson M, Ny T 1990 The structure of the TATA-less rat tissue-type plasminogen activator gene. J Biol Chem 265:2022-2027

30. Melton DA, Krieg PA, Rebagliati MR, Maniatis T, Zinn K, Green MR 1984 Efficient in vitro synthesis of bioactive RNA and RNA hybridization probes from plasmids containing a bacteriophage SP6 promoter. Nucleic Acids Res 12:7035-7056

31. Chomczynski P, Sacchi N 1987 Single-step method of RNA isolation by acid guanidinium thiocyanate-phenol-chloroform extraction. Anal Biochem 162:156-159

32. Ohlsson M, Hsueh AJW, Ny T 1988 Hormonal regulation of tissue- type plasminogen activator ribonucleic acid levels in rat granulosa cells: mechanism of induction by follicle-stimulating hormone and gonadotropin-releasing hormone. Mol Endocrinol 2:854-861

33. LaPolt PS, Oikawa M, Jia X-C, Dargan C, Hsueh AJW 1990 Gonadotropin-induced up- and down-regulation of rat ovarian LH receptor message levels during follicular growth, ovulation and luteinization. Endocrinology 126:3277-3279

34. Mathews LS, Vale WW 1991 Expression cloning of an activin receptor, a predicted transmembrane serine kinase. Cell 65:973-982

35. Means AR, Vaitukaitis J 1972 Peptide hormone "receptors:" specific binding of ${ }^{3} \mathrm{H}-\mathrm{FSH}$ to testis. Endocrinology 90:39-46

36. Cole FE, Weed JC, Schneider GT, Holland JB, Geary WL, Levy DL, Huseby RA, Rice BF 1976 The specificity of gonadotropin binding by the human corpus luteum. Fertil Steril 27:921-928

37. Wahlstrom T, Huhtaniemi I, Hovatta O, Seppala M 1983 Localization of luteinizing hormone, follicle-stimulating hormone, prolactin, and their receptors in human and rat testis using immunocytochemistry and radioreceptor assay. J Clin Endocrinol Metab 57:825830

38. Catt KJ, Tsuruhara T, Dufau L 1972 Gonadotropin binding sites of the rat testis. Biochim Biophys Acta 279:194-201

39. Heckert LL, Griswold MD 1991 Expression of follicle-stimulating hormone receptor mRNA in rat testis and Sertoli cells. Mol Endocrinol 5:670-677

40. Tilly JL, LaPolt PS, Hsueh AJW 1992 Hormonal regulation of follicle-stimulating hormone receptor messenger RNA levels in cultured rat granulosa cells. Endocrinology 130:1296-1302

41. Camp TA, Rahal JO, Mayo KE 1991 Cellular localization and hormonal regulation of follicle-stimulating hormone and luteinizing hormone receptor mRNAs in the rat ovary. Mol Endocrinol 5:14051417

42. Roche PC, Ryan RJ 1989 Purification, characterization, and aminoterminal sequence of the ovarian receptor for luteinizing hormone/ human choriogonadotropin. J Biol Chem 264:4636-4641

43. Dattatreyamurty B, Zhang S-B, Reichert Jr LE 1990 Purification of follitropin receptor from bovine calf testes. J Biol Chem 265:54945503

44. Reichert Jr LE, Dattatreyamurty B, Grasso P, Santa-Coloma TA 1991 Structure-function relationships of the glycoprotein hormones and their receptors. Trend Pharmacol Sci 12:199-203

45. Shin J, Ji TH 1985 Photoaffinity labeling of the follitropin receptor J Biol Chem 260:14020-14025

46. Podesta EJ, Solano AR, Attar R, Sanchez ML, Molina-Veda L 1983 Receptor aggregation induced by antilutropin receptor antibody and biological response in rat testis Leydig cells. Proc Natl Acad Sci USA 80:3986-3990

47. Dias JA, Gates SA, Reichert Jr LE 1982 Evidence for the presence of follicle-stimulating hormone receptor antibody in human serum. Fertil Steril 38:330-338

48. Chiauzzi V, Cigorra S, Escobar ME, Rivarola MA, Charreau EH 1982 Inhibition of follicle-stimulating hormone receptor binding by circulating immunoglobulin. J Clin Endocrinol Metab 54:1221-1228

49. van Weissenbruch MM, Hoek A, van Vliet-Bleeker I, Schoemaker J, Drexhage H 1991 Evidence for the existence of immunoglobulins that block ovarian granulosa cell growth in vitro. A putative role in resistant ovary syndrome. J Clin Endocrinol Metab 73:360-367

50. Shon M, Gerimo J, Bastia D 1982 The nucleotide sequence of replication origin $\beta$ of the plasmid R6K. J Biol Chem 257:1382313827 